\title{
Food habits and trophic niche overlap of the red fox and the stone marten in a Mediterranean rural area
}

\author{
Paola SERAFINI and Sandro LOVARI*
}

Serafini P. and Lovari S. 1993. Food habits and trophic niche overlap of the red fox and the stone marten in a Mediterranean rural area. Acta theriol. 38: $233-244$.

The food habits of the red fox Vulpes vulpes (Linnaeus, 1758) and the stone marten Martes foina (Erxleben, 1777) were studied in a rural hilly area in Siena county, central Italy, using faecal analysis. Both frequency of occurrence and volume of the different foods were quantified. Rodents, especially Apodemus sp., were an important prey for both species. Predation on poultry and game birds was nearly absent, whereas fruits and insects were seasonally taken by both species. Rosaceae fruits were the most eaten plant item. Within this category the fox fed mainly on Malus sp. and Pyrus sp., while the marten showed a preference for Rubus sp. and Sorbus domestica. Only fruits of Prunus spinosa were eaten in comparable quantities. Beetles were well represented in the diet of both carnivores, although they tended to concentrate on different species. Grasshoppers were preyed in small quantity. The overall diet overlap of foxes and stone martens was extensive: a surprising result, if the different body size, locomotor adaptations and living habits of these carnivores are considered.

Department of Evolutionary Biology, Ethology and Behavioural Ecology Group, University of Siena, via P. A. Mattioli 4, 53100 Siena, Italy

Key words: Vulpes vulpes, Martes foina, diet, seasonal variation, niche overlap, Italy

\section{Introduction}

Very few studies have been carried out on the food habits of the stone marten Martes foina (Erxleben, 1777), especially in southern Europe (Denmark: Rasmussen and Madsen 1985; France: Waechter 1975, Clement and Saint-Girons 1982; Germany: Ansorge 1989; Italy: Pozio and Gradoni 1981, Lucherini and Crema 1993; Mongolia: Chotolchu et al. 1980; Poland: Romanowski 1989; Spain: Delibes 1978) and in no area its diet has been compared with that of the red fox Vulpes vulpes (Linnaeus, 1758) to find out their ecological relationships.

The red fox and the stone marten have different body size (red fox weight: 6 $7 \mathrm{~kg}$; stone marten weight: $0.7-1.0 \mathrm{~kg}$ ), different social organisation (one male and one to several female foxes may share the same territory, e.g. Macdonald 1987, whereas martens seem to be intrasexually territorial, e.g. Krüger 1990), and partly different activity rhythms (foxes are less nocturnal than martens although apparently both species tend to be active mostly at sunset and sunrise, e.g. Kalpers

\footnotetext{
* Requests for reprints should be sent to Sandro Lovari
} 
1984, Harris 1986, Cavallini and Lovari 1991, Posillico et al. 1992). Furthermore, the stone marten is a much better rock and tree climber than the red fox. Food habits could then be expected to show little similarity. Accordingly, Ciampalini and Lovari (1985) found out an extensive overlap of food habits between two similar-sized carnivores, the red fox and the Eurasian badger Meles meles, but almost no overlap was revealed between two different-sized ones, the red fox and the wolf Canis lupus (Patalano and Lovari 1993). Conversely, it could be argued that two species of different morphology and other adaptations may feed on the same food resource without ever coming into open conflict with each other. This may lead to a diffuse scramble competition. Whether such a competition leads to niche separation or just limitation of population densities, it will presumably depend on the specific circumstances. In fact, Goszczyński (1986) and Cantini (1991) found out a rather extensive overlap in the food habits of sympatric red foxes and martens, but these authors could not discriminate between scats belonging to the stone and pine martens (see also Lindström 1989). According to the principle of competitive exclusion (e.g. Odum 1983), sympatric stone and pine martens are likely to specialise on different food resources to coexist, thus expanding the overall trophic niche of Martes sp. to overlap with that of the fox (Marchesi et al. 1989, Cantini 1991). Cantini (1991) concluded that the remarkable dietary similarity between foxes and martens may then be more apparent than actual. Our study area was not inhabited by pine martens, which prevented errors of scat identification between these closely related mustelids.

The aims of our research were the following: (1) to find out the food habits of the stone marten and the red fox in a rural Mediterranean area, (2) to assess the extent of their diet overlap in a region where pine martens are not present, (3) to test the hypothesis that widely different species are likely to fill separate trophic niches.

\section{Study area}

This study has been carried out in a rural hilly area of about 900 ha in Siena county, central Italy $\left(43^{\circ} 18^{\prime} \mathrm{N}, 11^{\circ} 05^{\prime} \mathrm{E}\right)$, at an altitude of $150-370 \mathrm{~m}$ a.s.l. Twenty five to thirty foxes were estimated to live in our study area, with a density of about 3 individuals $/ 100$ ha. Territory size could be estimated around 100 ha, with a sex ratio of 1 male : 2 females / territory. Territory size of stone martens ranged around $350-400 \mathrm{ha}$, with an approximate density of 0.7 individuals $/ 100 \mathrm{ha}$. The area is covered with mixed oakwood (Quercus ilex, Q. cerris, Q. pubescens, Fraxinus ornus, Carpinus betulus, Juniperus communis, J. oxycedrus, Spartium junceum), interspersed with fallow and cereal fields. Prunus spinosa, Pyrus pyraster, Malus sylvestris, Cornus mas, Rosa canina, Rosa sp., Rubus sp. were common in the wood margins, whereas Prunus domestica, P. avium, Pyrus communis, Malus domestica, Ficus carica, Sorbus domestica occurred in the neighbourhoods of 4 inhabited and 14 abandoned farms of the area. Hunting was allowed over about 450 ha, mainly aimed at pheasants and wild boars. So-called "fox control" operations also occurred (some 20 foxes, cubs included, were killed over the study area from mid-February to May 1991), as well as some songbird poaching. Several hundreds sheep were grazing over ca 400 ha. Mean temperatures during the research period ranged between $19.2^{\circ} \mathrm{C}$ (range: $12.4-24.8^{\circ} \mathrm{C}$ ) in May/October, and $6.8^{\circ} \mathrm{C}$ (range: $2.4-9.9^{\circ} \mathrm{C}$ ) in November/April. 


\section{Methods}

Between July 1990 and June 1991 a total of 340 scats of red fox and 378 scats of stone marten were collected in weekly excursions along a ca $16 \mathrm{~km}$ itinerary crossing the study area. The excrements were stored in polythene bags, deep-frozen and later analyzed as described by Kruuk and Parish (1981), Ciampalini and Lovari (1985), and Calisti et al. (1990). Each sample was washed in a tea-sieve (1.3 $\mathrm{mm}$ mesh) and the fine sediment was examined under a binocular microscope to detect the presence of earthworm chaetae. The food remains in scats were identified by comparison with reference material (e.g. hair, bones, feathers, seeds). The recognition of hair was also based on the analysis of taxon-specific microscopical features (Faliu et al. 1980, Debrot et al. 1982). The identification of the small mammals was made by teeth characteristics (Toschi 1965). We called "unidentified material" what appeared in the scats as mostly homogeneus, often amorphous, components whose origin could not be traced. The few items (e.g. minute bone spikes, hair fragments) sometimes detected in such a matrix did not provide any useful clue for identification.

The relative volume (\% vol.) of each kind of food was assessed as described in Kruuk and Parish (1981), and Kruuk (1989).

The data were analysed on: (1) a monthly basis, as a percent frequency of occurrence (\% occ.) in the total sample and as percent of the total estimated volume. Only few scats of red foxes were found in January $(n=6)$ and February $(n=6)$, which we pooled together in our analysis. For purpose of comparison, marten scats underwent the same treatment. (2) a seasonal basis, combining the percent volume with the percent frequency.

\section{Statistics}

To evaluate the trophic niche breadths of the fox and the marten, we used the standardized Levins index $\left(B_{s t a}\right)$ (Colwell and Futuyma 1971). Their overlap was measured through Pianka index $(O)$ (1973), cf Ricklefs (1980). Both indices were applied to the percent occurrence and estimated volume of food categories in the whole diet.

The Levins index formula is:

$$
B=1 / \sum_{i=1}^{n} p i^{2}
$$

where $n$ is the number of food categories and $p$ is the proportion of records in each food category $(i)$ set at $100 \%$. The standardized Levins index formula is:

$$
B_{s t a}=B-1 / B_{\max }-1
$$

where $B$ is the Levins index (Levins 1968) and $B_{\max }$ is the total number of food categories recognised (lowest niche breadth $=0$, greatest niche breadth $=1$ ).

The Pianka index formula is:

$$
O_{j k}=\sum_{i=1}^{n} p_{i j} p_{i k} / \sqrt{\left(\sum_{i=1}^{n} p_{i j}{ }^{2} \sum_{i=1}^{n} p_{i k}{ }^{2}\right)}
$$

where $p_{i j}$ (or $p_{i \mathrm{k}}$ ) is the proportion of the food category $i$ recorded in the diet of the species $j$ (or $k$ ).

The differences in diet of the main food categories (rodents, Rosaceae) eaten by both species were evaluated using the Mann-Whitney $U$-test, two-tailed (Siegel 1956). Correlations between environmental variables and occurrence/volume of food items in the diet were tested using the Spearman rank correlation coefficient (Siegel 1956). 


\section{Results}

\section{Red fox}

Rosaceae fruits, ungulates (sheep carrion), rodents and beetles made the staple of the fox diet (Figs 1, 3 and 4). The use of Rosaceae fruits (Malus sp., Pyrus sp., Prunus spinosa) increased rapidly from early summer to the autumn (Table 1, Figs 3 and 4), when most fruits are available on the ground, after falling from the trees. In late summer and early autumn Cornaceae fruits (Cornus mas, mainly) and, to a lesser extent, figs were also taken (Figs 3 and 4). In late winter and
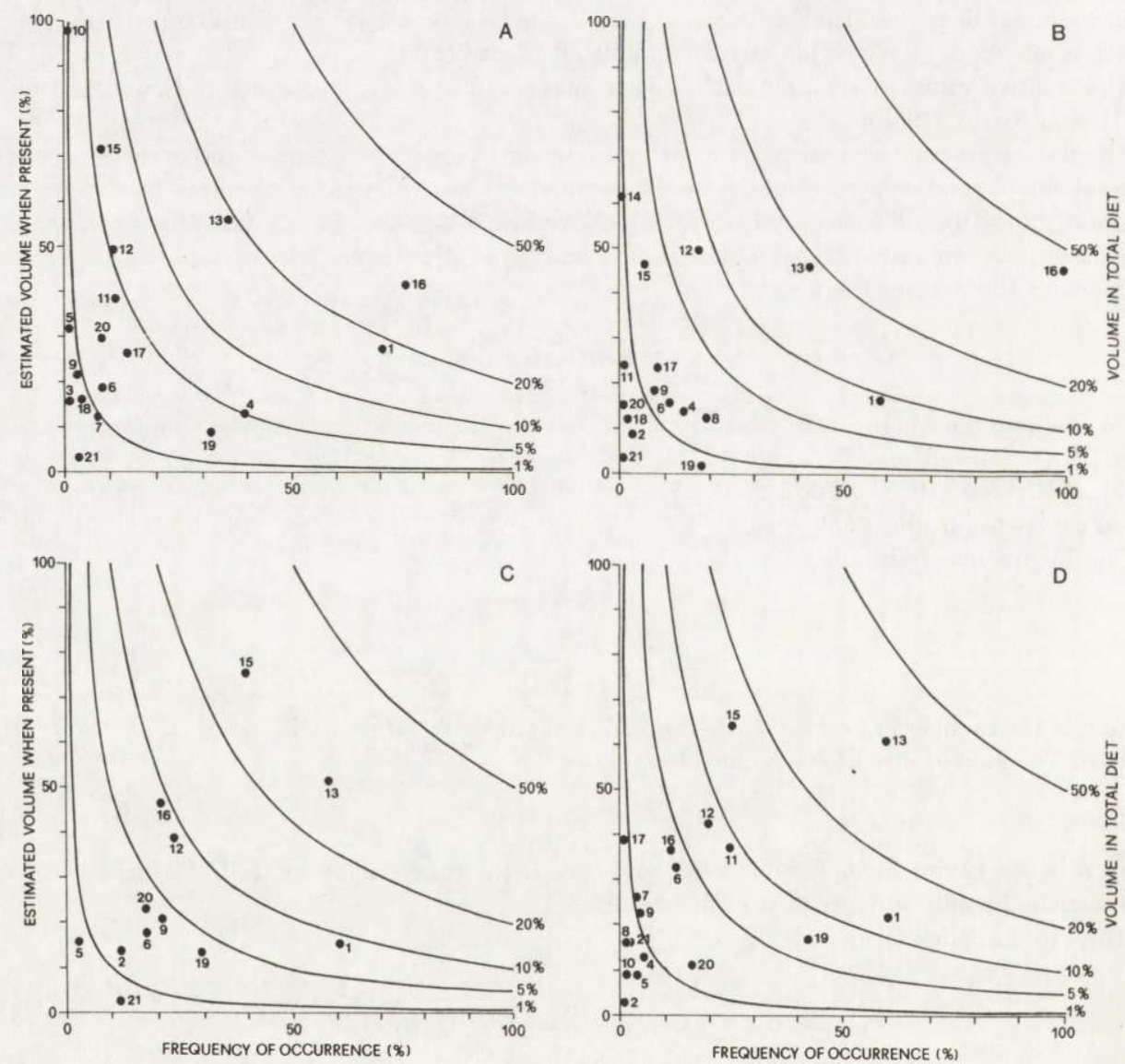

Fig. 1. Estimated volume of red fox food categories versus their frequency of occurrence. A - summer (J-A-S), B - autumn (O-N-D), C - winter (J-F-M), D - spring (A-M-J). Isopleths connect points of equal relative volume in the overall diet. 1 - Coleoptera, 2 -Dermaptera, 3 -Hymenoptera, 4 - Orthoptera, 5 - other insects, 6 - larvae, 7 - Myriapoda, 8 -Arachnida, 9 - Mollusca, 10 - other invertebrates, 11 - Reptilia, 12 - Aves, 13 - Rodentia, 14 - Lagomorpha, 15 - Artiodactyla, 16 - Rosaceae, 17 Cornaceae, 18 - Moraceae, 19 - other plant material, 20 - garbage, 21 - unidentified material. 
early spring rodents and ungulates (sheep carrion and offal, $75 \%$ occ.; wild boar carcasses, $15.4 \%$ occ.; undetermined carcasses, $9.6 \%$ occ.) peaked in the fox diet, while fruits were absent (Figs 3 and 4). Among rodents, field mice Apodemus sp. were the most preyed upon species $(37.8 \%$ occ., $35.1 \%$ vol.) in spring. Bank voles Clethrionomys glareolus built up $7.6 \%$, in occ., and $6.7 \%$, in vol., of the diet. Beetles were taken throughout the year, but their bulk was rarely more than $20 \%$ in diet (Figs 1, 3 and 4). Lamellicornia (mainly Scarabaeidae) were taken in late spring and summer, whereas Carabidae peaked in late summer and early autumn. The consumption of reptiles (colubrid snakes, $50 \%$ occ.; lizards, $27.5 \%$ occ.; undetermined, $22.5 \%$ occ.), grasshoppers and garbage was restricted to the warm months, but no category appeared important (Figs 3 and 4). In the cold season occasionally foxes preyed on slugs (Limax limax). Earthworms did not show up in the diet, but in one sample (one chaeta). While the use of grasshoppers was positively associated
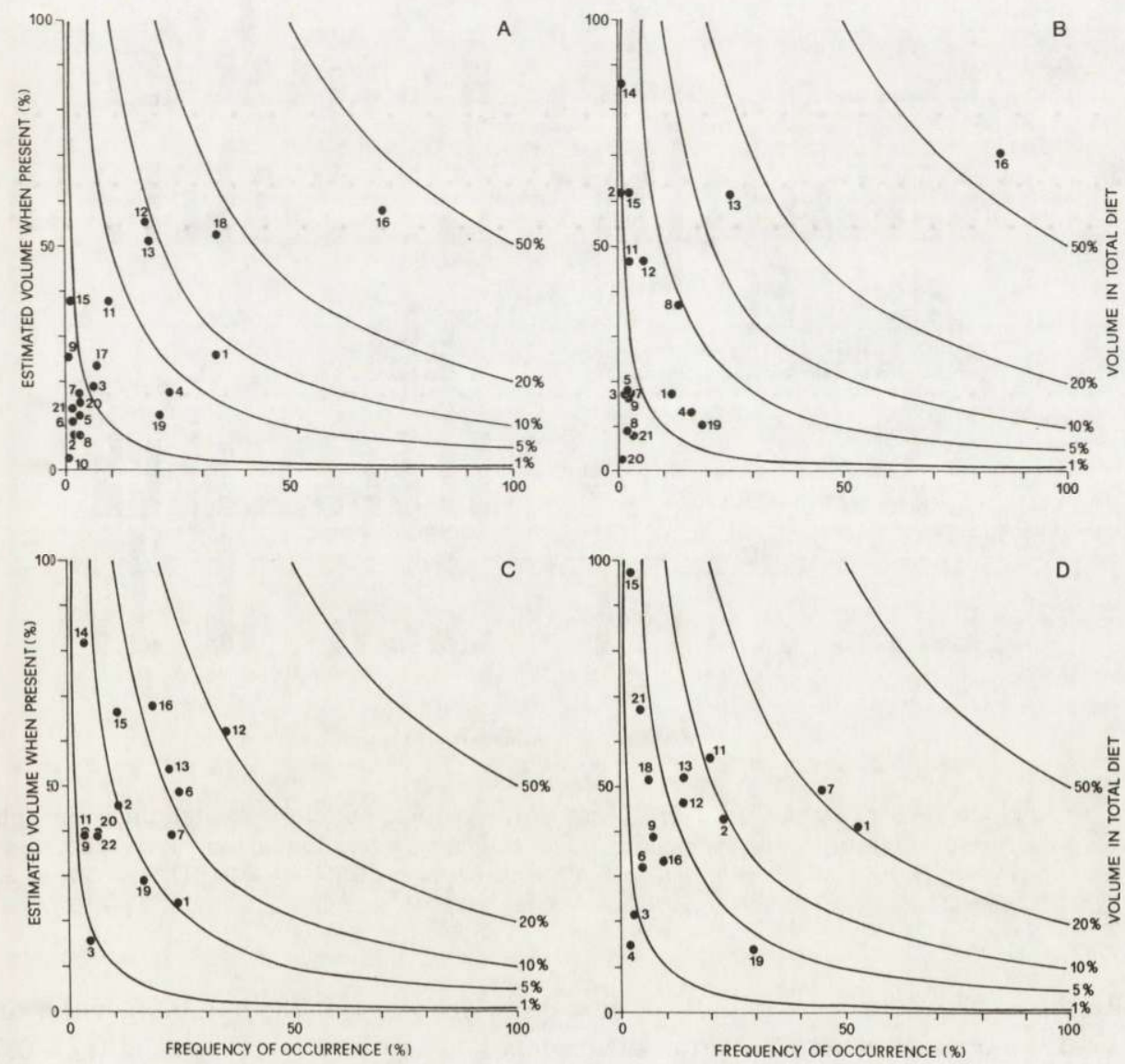

Fig. 2. Estimated volume of stone marten food categories versus their frequency of occurrence. 22 - eggs. Other denotations as in Fig. 1. 


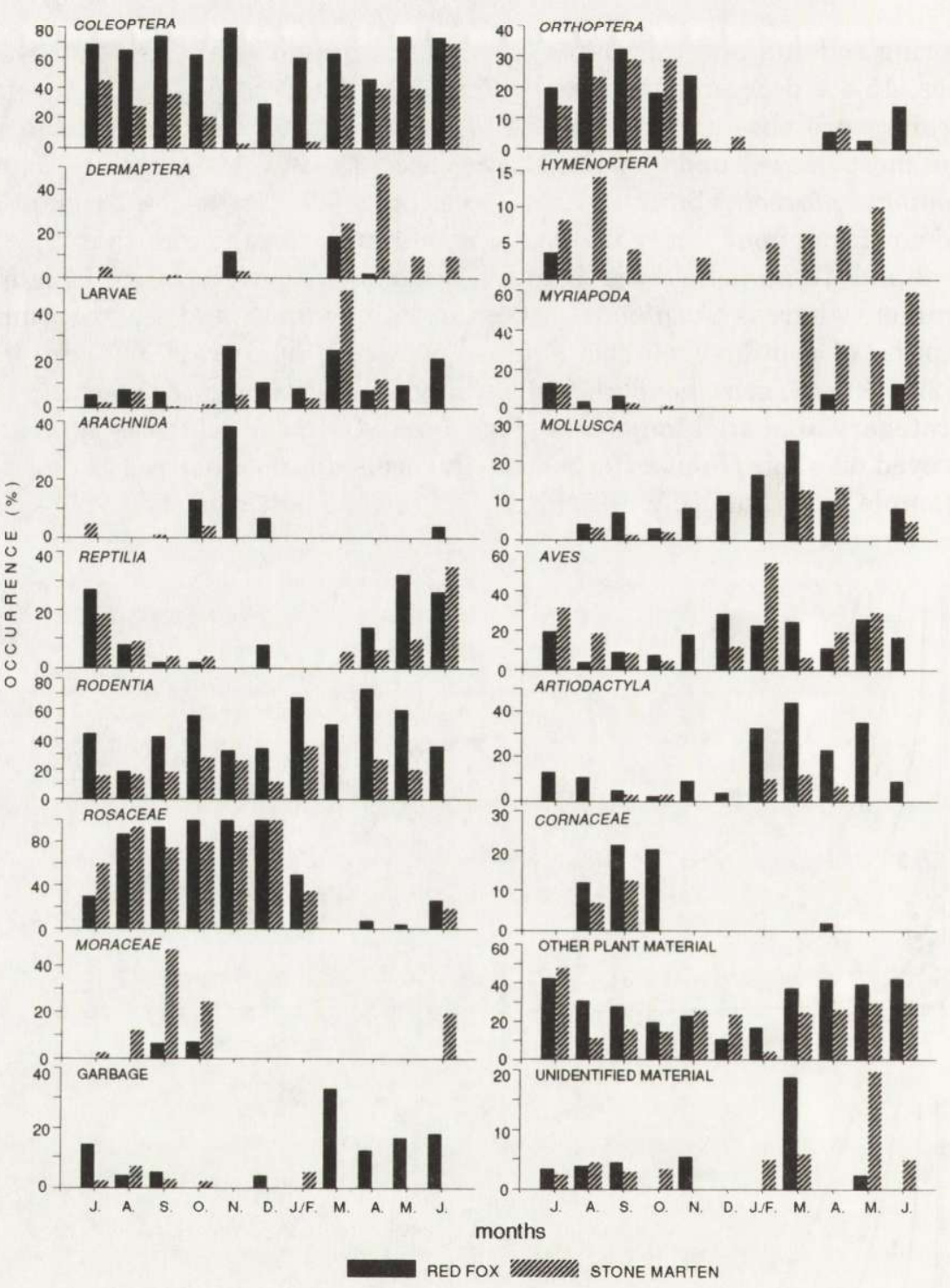

Fig. 3. Percentage of occurrence of food categories in the red fox and stone marten diets throughout the research period. Monthly sample size ( $n_{1}$ refers to fox; $n_{2}$ refers to marten): J, $n_{1}=30, n_{2}=38$; $\mathrm{A}, n_{1}=26, n_{2}=43 ; \mathrm{S}, n_{1}=43, n_{2}=99 ; \mathrm{O}, n_{1}=40, n_{2}=61 ; \mathrm{N}, n_{1}=34, n_{2}=31 ; \mathrm{D}, n_{1}=27, n_{2}=25$; J-F, $n_{1}=12, n_{2}=20 ; \mathrm{M}, n_{1}=16, n_{2}=16 ; \mathrm{A}, n_{1}=52, n_{2}=15 ; \mathrm{M}, n_{1}=37, n_{2}=10 ; \mathrm{J}, n_{1}=23, n_{2}=20$.

to the mean temperature $\left(r_{\mathrm{s}}=0.64, p<0.05\right.$, occ.; $r_{\mathrm{s}}=0.73, p<0.05$, vol.), only the beetle percent volume (but not occurrences) was directly correlated $\left(r_{\mathrm{s}}=0.77\right.$, $p<0.05$ ). 


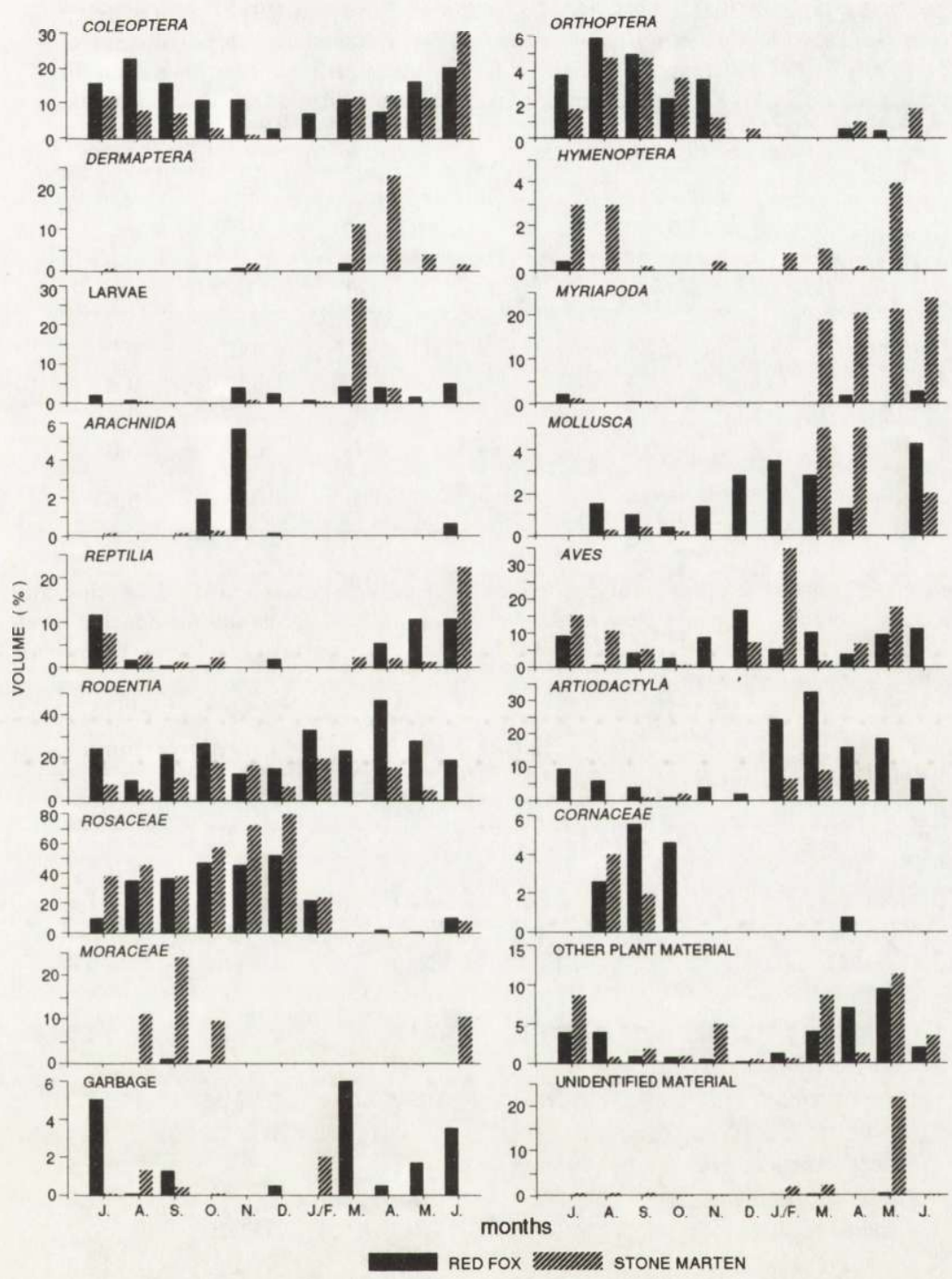

Fig. 4. Percentage of volume of food categories in the red fox and stone marten diets throughout the research period. Scat sample sizes as in Fig. 3.

\section{Stone marten}

Fruits were the staple of the stone marten diet for most of the year, showing a clear seasonality (Fig. 2). The use of Rosaceae fruits (Figs 2, 3 and 4) increased sharply from June to December becoming, together with figs, one of the main components of the diet. Birds (Passeriformes, $52.8 \%$ occ.; Galliformes, $11.3 \%$ occ.; 
Table 1. Trophic niche breadth (Colwell and Futuyma 1971) and overlap (Pianka 1973) of Vulpes vulpes and Martes foina, based on the percentage of occurrence and estimated volume. $B_{\text {sta }} \mathrm{f}-$ standardized Levins index, in occurrences; $B_{\text {sta }} \mathrm{v}$ - standardized Levins index, in volume; $O_{\mathrm{f}}$ - Pianka index, in occurrences; $O_{\mathrm{v}}$ - Pianka index, in volume; $n$ - number of food categories.

\begin{tabular}{|c|c|c|c|c|c|c|}
\hline \multirow[t]{2}{*}{ Season } & \multicolumn{2}{|c|}{$\begin{array}{l}\text { Vulpes vulpes } \\
\quad(n=35)\end{array}$} & \multicolumn{2}{|c|}{$\begin{array}{l}\text { Martes foina } \\
\quad(n=37)\end{array}$} & \multirow[t]{2}{*}{$O_{\mathrm{f}}$} & \multirow[t]{2}{*}{$O_{\mathrm{v}}$} \\
\hline & $B_{s t a} \mathrm{f}$ & $B_{\text {sta }} \mathrm{v}$ & $B_{s t a} \mathrm{f}$ & $B_{s t a \mathrm{~V}}$ & & \\
\hline Summer & 0.4 & 0.4 & 0.4 & 0.4 & 0.8 & 0.5 \\
\hline Autumn & 0.4 & 0.4 & 0.2 & 0.1 & 0.5 & 0.4 \\
\hline Winter & 0.6 & 0.4 & 0.6 & 0.6 & 0.7 & 0.6 \\
\hline Spring & 0.4 & 0.3 & 0.4 & 0.4 & 0.7 & 0.6 \\
\hline Annual & 0.3 & 0.4 & 0.4 & 0.3 & 0.8 & 0.6 \\
\hline
\end{tabular}

Table 2. Differential frequency of occurrence of food categories (carabid beetles and rose fruits) used by Vulpes vulpes and Martes foina, split to genus and/or species level. Family sub-totals (in bold) refer to annual total diet; values for lower taxonomic categories refer to each family.

\begin{tabular}{|c|c|c|c|c|}
\hline \multirow{2}{*}{ Food category } & \multicolumn{2}{|c|}{ Vulpes vulpes } & \multicolumn{2}{|c|}{ Martes foina } \\
\hline & $n$ & $\%$ & $n$ & $\%$ \\
\hline \multicolumn{5}{|l|}{ Coleoptera } \\
\hline Carabidae & 169 & 49.7 & 83 & 21.9 \\
\hline Carabus morbillosus & 5 & 2.7 & - & - \\
\hline Carabus rossii & 45 & 20.5 & 10 & 9.6 \\
\hline Carabus violaceus & 25 & 11.4 & 8 & 7.7 \\
\hline Carabus sp. & 6 & 2.7 & 2 & 1.9 \\
\hline Cychrus italicus & 1 & 0.5 & - & - \\
\hline Percus payculli & 18 & 8.2 & 19 & 18.3 \\
\hline Percus sp. & - & - & 7 & 6.7 \\
\hline Procrustes coriaceus & 14 & 6.4 & 6 & 5.8 \\
\hline Pterostichus bicolor & - & - & 1 & 1.0 \\
\hline Scarites buparius & - & - & 7 & 6.7 \\
\hline Zabrus tenebrioides & 31 & 14.2 & 17 & 16.3 \\
\hline Unidentified & 74 & 33.8 & 27 & 26.0 \\
\hline Rosaceae & 191 & 56.2 & 240 & 63.5 \\
\hline Malus sp. & 83 & 34.9 & 17 & 6.0 \\
\hline Prunus avium & 1 & 0.4 & 10 & 3.5 \\
\hline Prunus spinosa & 76 & 31.9 & 93 & 32.6 \\
\hline Prunus sp. & 3 & 1.3 & 12 & 4.2 \\
\hline Pyrus sp. & 62 & 26.1 & 14 & 4.9 \\
\hline Rosa sp. & - & - & 3 & 1.1 \\
\hline Rubus sp. & 13 & 5.0 & 58 & 20.4 \\
\hline Sorbus sp. & - & - & 78 & 27.4 \\
\hline
\end{tabular}


Columbiformes, $3.8 \%$ occ.; undetermined, $32.1 \%$ occ.) and reptiles were eaten mainly in spring and summer, but rodents were a constant component of the diet throughout the year (Figs 3 and 4). Field mice Apodemus sp. were the rodent species most preyed upon ( $45.2 \%$ occ., $46.5 \%$ vol.). During summer Orthoptera peaked up. Larvae and adult beetles were found in the marten diet during the whole year, except the coldest months. Large Lamellicornia beetles (mainly Lucanidae and Scarabaeidae) were important food items in summer, whereas Carabidae peaked in spring (Table 1). Myriapoda and Dermaptera were also taken in the latter season (Figs 2, 3 and 4).

The use of reptiles (lizards, $62.1 \%$ occ.; colubrid snakes, $34,5 \%$ occ.; undetermined, $3.4 \%$ occ.) was directly associated to the mean temperature $\left(r_{\mathrm{s}}=0.78\right.$, $p<0.05$, occ.; $r_{\mathrm{s}}=0.81, p<0.05$, vol.) and negatively correlated to precipitation $\left(r_{\mathrm{s}}=-0.67, p<0.05\right.$, vol.). Positive correlations to the mean temperature were also found for beetles $\left(r_{\mathrm{s}}=0.66, p<0.05\right.$, occ.; $\mathrm{r}_{\mathrm{s}}=0.65, p<0.05$, vol. $)$ and Moraceae $\left(r_{\mathrm{s}}=0.73, p<0.05\right.$, occ.; $r_{\mathrm{s}}=0.79, p<0.05$, vol.). Garbage was rarely taken.

Trophic niche breadth and overlap

The annual value of the trophic niche breadth of the red fox $\left(B_{s t a}=0.3\right.$ in occurrences; 0.4 in volume) is relatively low. Monthly values ranged from 0.4 to 0.7 , in occurrences, and from 0.3 to 0.6 , in volume, the cold months showing the highest value. The annual trophic niche breadth of the stone marten matches well those reported for two areas of the Alpine Arch (Cantini 1991, Lucherini and Crema 1993), and its values are the same of the fox's (Table 1). Monthly variation is great: $0.2-0.7$, in occurrences; $0.1-0.6$, in volume. Autumn values are the smallest and winter ones stand as the highest. The niche overlap is extensive, nearing total overlap (annual, in occurrences), and showing the smaller values in autumn (Table 1). If several food categories are broken down into smaller units (Table 2), some remarkable differences are detectable, e.g. Carabus rossii is preferred by the fox, while Percus payculli is mainly eaten by the marten; apples and pears are taken by the former, whereas the latter feeds on blackberries and sorb-apples (Table 2). If the food categories listed in Table 2 are not considered, the annual trophic niche overlap increases from 0.8 to 0.9 (in occurrences) and from 0.6 to 0.8 (in volume) (cf Table 1 ).

\section{Discussion}

Abundance, availability and dispersion of food resources are important factors underlying the food habits and habitat use of carnivores (e.g. Macdonald 1981, Doncaster et al. 1990, Cavallini and Lovari 1991). In turn, climatic/seasonal variation in the diet of both the red fox and the stone marten, two euriphagous species, is not surprising. The fox used mainly three food resources: Rosaceae fruits and, to a lesser extent, rodents (summer, autumn); rodents and scavenged larger mammals (winter, spring). The marten mostly based its diet on Rosaceae fruits, rodents as well as figs in summer and autumn, while wild birds and Rosaceae 
fruits, in winter, and beetles as well as large centipedes, in spring, were the staple. Thus, the marten seemed to shift its food habits seasonally more than the fox (Figs 1 and 2), making use of a number of main (i.e. 10\% isopleth in Figs 1 and 2) diet components twice as large as that of the latter, 8 versus 4 , although the overall number of food categories differed little in the two species (see Table 1). The remarkable use which both carnivores made of fruits and other plant items may be explained as (A) a preference for it, or (B) a consequence of seasonal availability, or (C) an obligate diet when sources of animal proteins (e.g. rodents, carrion, insects) are scarce. Carnivores possess a short and simple digestive tract, unsuitable to process most vegetal food. They would then have difficulty meeting their energy and nutrient requirements on an exclusively vegetarian diet (Cavani 1991, Ball and Golightly 1992). Proteins are especially needed to build up and to restore body mass. In case of scarcity or unavailability of animal proteins, some carnivores can survive by taking plant food, e.g. fruits and berries, often in large quantities to compensate for limited actual digestion (the giant panda being an extreme example, Schaller et al. 1985). It may also be noted that the simple carbohydrates in fruits and berries do not require any special adaptation of the digestive system to be digested. Furthermore, both the stone marten and the red fox have been shown to be opportunistic species (e.g. Marchesi et al. 1989, Cavallini and Lovari 1991, Prigioni 1991), which tend to take what is most available. We think that a combination of reasons (B) and (C) may explain why their diet can be based so extensively on plant food, i.e. fruits and berries. Within this category, preferences are likely to occur.

In summer the trophic niche overlap of these carnivores tends to be greater than in the other seasons. In particular, while their diets are qualitatively similar, some differences can be detected in the quantity of the food categories used. In the warm months, reptiles tended to appear relatively more often in the fox's than in the marten's diet, while bird remains showed up more frequently in the scats of martens. The different climbing ability of these carnivores may partly have determined food selection: e.g. in summer, apples and pears can be found also on the ground where foxes can take them, but sorb-apples and wild plums are still on trees, where only martens may get access to them. The lowest value of diet overlap has been found in autumn: both species fed largely on fruits, most abundant in this season in Mediterranean countries, but, while the fox still went for apples and pears, the marten took figs and sorb-apples. Not surprisingly, the diet overlap grows again in the cold season, when the array of potential food resources decreases. However, within the animal food taken from December through March, the marten concentrated on invertebrates, while the fox used carrion and rodents. In particular, the marten fed steadily on bees and wasps throughout the year, although in limited amounts (Figs 3 and 4). Delibes (1978) suggests that stone martens feed on honey in all seasons and that often their scats smell of honey, show the presence of wax and sometimes contain bee remains. These characteristics are likely to be associated to honey consumption, but we could detect 
traces of wax and honey only rarely in our sample (where, on the other hand, Hymenoptera were commonly found). This inconsistency may depend on the difficulty of detecting direct and indirect traces of a small quantity of honey in scats.

We cannot conclude that competition occurs between foxes and martens, but our data have shown that, when opportunist species are concerned, a large overlap of food habits can occur even if body size, locomotor adaptations, social organisation and activity differ widely. However, some of our results suggest that a greater trophic niche separation may not be ruled out, if food habits are analysed in fine detail, i.e. by breaking down the food categories into smaller units.

Acknowledgements: We wish to thank the Agreste Mensano Agency for providing practical facilities and lodging. A. Mazzanti, S. Cennini and R. Mazzoni della Stella cooperated greatly in various aspects of our research. M. Patalano and C. Pesarini helped in the identification of some food items. M. T. Corsini, P. Frigerio, M. Posillico, C. Riccardi, M. Ricci-Lucchi and P. Valier provided assistance in field and/or laboratory work. E. Lindström, Z. Pucek and an anonymous referee read critically a previous draft of this paper. Funding was given by the Amministrazione Provinciale di Siena. We are grateful to all of them.

\section{References}

Ansorge H. 1989. Die Ernährungsökologie des Steinmarders Martes foina in den Landschaftstypen der Oberlausitz. Populationsökologie Marderartiger Säugetiere, Wiss. Beitr. Univ. Halle: $473-493$.

Ball L. C. and Golightly R. T., Jr 1992. Energy and nutrient assimilation by gray foxes on diets of mice and Himalaya berries. J. Mammal. 73: 840 - 846 .

Calisti M., Ciampalini B., Lovari S. and Lucherini M. 1990. Food habits and trophic niche variation of the red fox Vulpes vulpes (L., 1758) in a Mediterranean area. Revue d'Ecologie 45: 410 - 419.

Cantini M. 1991. Alimentazione della volpe (Vulpes vulpes) in aree boscate delle Alpi Orobie. Atti I Simp. Ital. Carnivori. Hystrix (n.s.) 3: $83-89$.

Cavallini P. and Lovari S. 1991. Environmental factors influencing the use of habitat in the red fox Vulpes vulpes. J. Zool., Lond. 223: $323-339$.

Cavani C. 1991. Qualità della dieta della volpe (Vulpes vulpes) in un'area costiera mediterranea (Italia centrale). Hystrix (n.s.) 3: 63.

Chotolchu N., Stubbe M. and Dawaa N. 1980. Der Steinmarder Martes foina (Erxleben, 1777) in der Mongolei. Acta theriol. 25: 105 - 114 .

Ciampalini B. and Lovari S. 1985. Food habits and trophic niche overlap of the Badger (Meles meles) and the Red fox (Vulpes vulpes) in a Mediterranean coastal area. Z. Säugetierk. 50: $226-234$.

Clement R. and Saint Girons M. C. 1982. Notes sur les mammiferes de France. XVIII. Le régime de la fouine, Martes foina (Erxleben, 1777), dans l'agglomération nantaise et en milieu rural. Mammalia 46: $550-553$.

Colwell R. R. and Futuyma D. J. 1971. On the measurement of niche breadth and overlap. Ecology 52: $567-572$.

Debrot S., Fivaz G., Mermod C. and Weber J. M. 1982. Atlas des poils des mammiferes d'Europe. Institut de Zoologie, Neuchâtel: $1-208$.

Delibes M. 1978. Feeding habits of the stone marten, (Martes foina Erxleben, 1777) in northern Burgos, Spain. Z. Säugetierk. 43: $282-288$.

Doncaster C. P., Dickman C. R. and Macdonald D. W. 1990. The feeding ecology of red foxes in the city of Oxford, England. J. Mammal. 71: 188 - 194.

Faliu L., Lignereux Y. and Barrat J. 1980. Identification des poils des mammiferes pyreneens. Doñana Acta Verteb. 1: $125-212$.

Goszczyński J. 1986. Diet of foxes and martens in central Poland. Acta theriol. 31: $491-506$. 
Harris S. 1981. The food of suburban foxes (Vulpes vulpes), with special reference to London. Mammal Rev. 11: $151-168$.

Harris S. 1986. Urban foxes. Whittet Editions, London: 1 - 128.

Kalpers J. 1984. Contribution à l'étude éco-ètologique de la Fouine (Martes foina): Stratégie d'utilisation du domaine vital et des ressources alimentaires. Cahiers d'Ethol. Appl. 4: 11 - 26.

Krüger H. H. 1990. Home ranges and patterns of distribution of stone and pine martens. Trans. 19th IUGB Congress. Trondheim 1989: 348 - 349.

Kruuk H. 1989. The social badger. Oxford University Press, Oxford: $1-156$.

Kruuk H. and Parish T. 1981. Feeding specialization of the European badger (Meles meles) in Scotland. J. Anim. Ecol. 50: 773 - 788.

Levins R. 1968. Evolution in changing environments. Princeton Univ. Press, Princeton.

Lindström E. 1989. The role of medium-size carnivores in the Nordic boreal forest. Finnish Game Res. 46: $53-63$.

Lucherini M. and Crema G. (1993) Diet of urban stone martens in Italy. Mammalia 57: $274-277$.

Macdonald D. W. 1981. Resource dispersion and the social organization of the red fox (Vulpes vulpes). Proc. Worldwide Furbearer Conf. 1: 918 - 949.

Macdonald D. W. 1987. Running with the fox. Unwin-Hyman, London and Sidney: $1-224$.

Marchesi P., Lachat N., Lienhard R., Debiève P. and Mermod C. 1989. Comparaison des régimes alimentaires de la fouine et de la martre dans une région du Jura Suisse. Rev. Suisse Zool. 96: $281-296$.

Odum E. P. 1983. Basic ecology. CBS College Publishing, New York: $1-584$.

Patalano M. and Lovari S. 1993. Food habits and trophic niche overlap of the wolf (Canis lupus L. 1758) and the red fox Vulpes vulpes (L., 1758) in a Mediterranean mountain area. Revue d'Ecologie 48: $23-38$

Posillico M., Valier P. and Lovari S. 1992. Activity and ranging behaviour of a female stone marten: relationships with temperature and photoperiod. Atti 54 Congr. Uni. Zool. Ital., Perugia, 377 - 378.

Pianka E. R. 1973. The structure of lizard communities. Ann. Rev. Ecol. Syst. 4: 53 - 74.

Pozio E. and Gradoni L. 1981. Spettro trofico della volpe (Vulpes vulpes L.) e della faina (Martes foina Erxleben) in provincia di Grosseto. Natura, Milano, 72: 185 - 196.

Prigioni C. 1991. Lo studio della dieta della volpe Vulpes vulpes. Hystrix (n.s.) 3: $51-62$.

Rasmussen A. M. and Madsen A. B. 1985. The diet of the stone marten (Martes foina) in Denmark. Natura Jutl. 21: 141 - 144.

Ricklefs R. E. 1980. Ecology. Nelson \& Sons, Walton-on-Thames: 1 - 1185.

Romanowski J. 1989. Diet of stone marten in urban habitats. 5 Int. Theriol. Congr., Rome, $2: 974$.

Schaller G. B., Jinchu H., Wenshi P. and Jing Z. 1985. The giant pandas of Wolong. The University of Chicago Press, Chicago \& London: 1 - 182.

Siegel S. 1956. Nonparametric statistics for behavioral sciences. McGraw-Hill, New York: $1-312$.

Toschi A. 1965. Fauna d'Italia. Vol.7. Mammalia. Lagomorpha-Rodentia-Carnivora-Artiodactyla-Cetacea. Calderini, Bologna: 1 - 647.

Waechter A. 1975. Ecologie de la fouine en Alsace. La Terre et la Vie 29: 399 - 457.

Received 15 March 1993, accepted 2 June 1993. 